\title{
KEPRIBADIAN TOKOH UTAMA DALAM NOVEL AYAH MENYAYANGI TANPA \\ AKHIR KARYA KIRANA KEJORA \\ KAJIAN PSIKOLOGI SASTRA
}

(the Personality of main characters in father novel loves without the end of kirana kejora's works Literature psychological study)

\author{
Risman Iye ${ }^{a}$, Karim ${ }^{\mathrm{b}}$, Susiatic \\ acProgram Studi Sastra Indonesia Fakultas Sastra Universitas Iqra Buru \\ bInstitut Agama Islam Negeri (IAIN)Kendari \\ Pos-el; rismaniye@gmail.com
}

\begin{abstract}
Abstrak
Karya sastra merupakan salah satu sarana penanaman nilai-nilai kehidupan yang dapat dimanfaatkan oleh pembaca, karena karya sastra merupakan refleksi permasalahan kehidupan yang diungkapkan kembali oleh pengarang melalui tokoh-tokoh cerita. penelitian bertujuan untuk mengungkap Kepribadian Tokoh Utama Ayah dalam Novel Ayah Menyayangi Tanpa Akhir karya Kirana Kejora dalam kajian psikologi sastra. Metode dalam penelitian ini adalah deskriptif kualitatif. Data yang dimaksud dalam penelitian ini adalah kata, kalimat atau paragraf yang terdapat pada Kepribadian pada Tokoh Utama Ayah dalam Novel Ayah Menyayangi Tanpa Akhir karya Kirana Kejora dalam kajian. hasil penelitian ditemukan dalam kajian psikologi sastra pada novel Ayah Menyayangi Tanpa Akhir karya Kirana Kejora yaitu: Psikologi sastra dalam Aspek id, Aspek ego dan Aspek superego.
\end{abstract}

Kata Kunci: Kepribadian, Tokoh Utama. Novel.

\begin{abstract}
Abstrack
Literary works are a means of instilling life values that can be used by readers, because literary works are a reflection of life problems that are re-expressed by the author through the characters in the story. The research aims to uncover the Personality of Father Main Characters in the Novel Father Loves Endless work by Kirana Kejora in the study of literary psychology. The method in this research is descriptive qualitative. The data referred to in this study are words, sentences or paragraphs contained in the Personality of the Main Characters of Father in the Novel Father Loving Endlessly by Kirana Kejora in the study. research results found in the study of literary psychology in the novel Father Loves Without End by Kirana Kejora namely: Literary psychology in the aspects of id, aspects of the ego and aspects of the superego.
\end{abstract}

Keyword: Personality, Main Characters. Novel 


\section{PENDAHULUAN}

Karya sastra merupakan salah satu sarana penanaman nilai-nilai kehidupan yang dapat dimanfaatkan oleh pembaca, karena karya sastra merupakan refleksi permasalahan kehidupan yang diungkapkan kembali oleh pengarang melalui tokohtokoh cerita. Karya sastra atau kesusastraan berasal dari kata "susastra" yang memperoleh konfiks "ke-an". Dalam hal ini, "ke-an" mengandung makna tentang atau hal. Kata "susastra terdiri dari kata dasar "sastra" yang berarti tulisan yang mendapat awalan su yang artinya baik atau indah. Sehingga, secara etimologi kesusastraan berarti pembicaraan tentang berbagai tulisan yang indah bentuknya dan mulia isinya (Nursisto dalam R, Iye 2018).

Setiap pengarang selalu memiliki gaya sendiri yang berbeda antara yang satu dengan yang lainnya. Hal ini sesuai dengan sifat dan kegemaran pengarang masingmasing. Meskipun mereka mempunyai gagasan yang sama, bentuk penyampaiannya senantiasa berbeda. Hal ini merupakan kekhasan seorang pengarang dalam penciptaan sebuah karya sastra (Junaedie, 2005: 4).

Pada umumnya kepribadian tokoh utama disesuaikan dengan peranan tokoh tersebut, misalnya pengakarakterisasian terhadap tokoh protagonis dan penokohan terhadap tokoh antagonis. Melalui metode karakterisasi atau penokohan, pengarang dapat menggambarkan sifat dan prilaku para tokoh agar pembaca dapat memahami karakter dari setiap tokoh yang dihadirkan oleh pengarang. Selain penokohan, konflik juga menjadi hal yang tidak dapat dipisahkan dengan sebuah karya fiksi, karena konflik merupakan sebuah unsur yang esensial dalam pengembangan plot.

Novel sebagai salah satu bentuk karya sastra bermedia tulisan yang dapat mengemukakan sesuatu secara bebas, lebih banyak, dan melibatkan permasalahan yang lebih kompleks. Novel yang baik dibaca untuk penyempurnaan diri yang isinya dapat memanusiakan para pembacanya. Sebaliknya novel hiburan hanya dibaca untuk kepentingan santai saja, yang penting memberikan keasyikan bagi pembacanya. Bentuk-bentuk karya sastra berupa prosa, puisi, dan drama. Prosa dikelompokan menjadi dua bentuk yaitu: prosa lama dan prosa baru berupa cerpen dan novel. Sebagai karya sastra, novel merupakan suatu totalitas yang memiliki nilai seni. Totalitas itu dibangun oleh unsur-unsur pembangun karya satra yaitu: unsur intrinsik dan unsur ekstrinsik (Nurgiyantoro, 2002: 34)

Psikologi Sastra adalah analisis teks dengan mempertimbangkan relevansi dan peranan studi psikologis. psikologi sastra dapat dilakukan dengan dua cara, yaitu pertama, melalui pemahaman teori-teori psikologi kemudian dilakukan analisis terhadap suatu karya sastra. Kedua, dengan terlebih dahulu menentukan sebuah karya sastra sebagai objek penelitian, kemudian ditentukan teori-teori psikologi yang dianggap relevan untuk melakukan analisis. Pada umumnya metodologi penelitian yang pertama memiliki kecenderungan untuk menempatkan karya satra sebagai gejala sekunder sebab cara-cara penelitian yang dimaksudkan menganggap karya sastra sebagai gejala yang pasif, atau semata-mata sebgai objek untuk mengaplikasikan teori (Wiyatmi, 2006: 56).

Kepribadian tokoh utama merupakan unsur ekstrinsik yang terdapat dalam tubuh karya sastra itu sendiri. Unsur ekstrinsik merupakan Keadaan dilingkungan pengarang seperti religius, sosial, budaya, dan psikologi yang berpengaruh terhadap karya sastra, dan hal itu merupakan unsur 
ekstrinsik. Unsur-unsur inilah yang menyebabkan karya sastra hadir sebagai karya sastra. Penulis akan menganalisis kepribadian tokoh utama ayah dalam Novel Ayah Menyayangi Tanpa Akhir karya Kirana Kejora dalam kajian psikologi sastra, karena memberikan gambaran karakteristik novel kepribadian sosial, serta mendeskripsikan penggunaan tokoh yang menarik untuk diteliti.

Novel Ayah Menyayangi Tanpa Akhir ini menceritakan tentang perjalanan seorang ayah sebagai tokoh utama yang memberikan pelajaran berharga bagi anaknya. Kisah ini memberikan pelajaran bagi pembaca agar memahami arti keluarga dalam membangun kasih sayang yang sangat berharga. Dalam kajian psikologi sastra Novel ini menceritakan tragisnya seseorang yang berkarakter ganda, dimana Tokoh Utama (Arjuna) harus menjadi Ibu dan Ayah dalam menjaga anaknya, sehingga novel ini memberikan gambaran kehidupan untuk dijadikan pelajaran.

Penulis menganalisis Kepribadian Tokoh Utama Ayah dalam Novel Ayah Menyayangi Tanpa Akhir karya Kirana Kejora, karena novel ini memberikan deskripsi tokoh ayah (Arjun), yang membesarkan anaknya dengan penuh dinamika kehidupan, sehingga peran dan watak tokoh akan tergambar dalam Kepribadian Tokoh Utama Ayah. Selain itu, kajian psikologi sastra dalam pembahasan ide, ego, dan superego merupakan hal yang sangat penting untuk mengkaji kepribadian tokoh Ayah. Inilah yang menjadi salah satu alasan penulis mengambil judul Analisis Kepribadian Tokoh Utama Ayah dalam Novel Ayah Menyayangi Tanpa Akhir karya Kirana Kejora dalam kajian psikologi sastra.

\section{LANDASAN TEORI \\ Hakikat Kepribadian Tokoh}

Menurut Suharso, (2012: 223)

Kepribadian adalah perwatakan yang besifat Khas. Sedangkan tokoh adalah rupa wujud dan keadaan atau bentuk sifatnya. Jadi Kepribadian tokoh adalah perrwatakan yang mempunyai keadaan atau sifat khusus dalam sebuah karya sastra.

Seringkali tokoh disamakan dengan istilah Kepribadian ataupun watak, sejatinya hal itu adalah berlainan arti. Menurut Wiyatmi (2006: 30), tokoh adalah para pelaku yang terdapat dalam sebuah fiksi, sedangkan Kepribadian yang dalam bahasa induknya (Inggris) character merujuk pada istilah watak dalam bahasa Indonesia yang berarti kondisi jiwa ataupun sifat dari tokoh tersebut (Minderop, 2005: 2). Dapat disimpulkan, bahwa tokoh adalah pelaku yang berada dalam karya fiksi sedangkan kepribadian atau watak adalah perilaku yang mengisi diri tokoh tersebut.

Ada beberapa pendapat tentang pengertian lain mengenai tokoh. Sudjiman (2004: 16) menyatakan bahwa tokoh adalah individu rekaan yang mengalami berbagai peristiwa cerita dan berfungsi sebagai penggerak cerita. Tokoh adalah orang yang mengambil bagian dan mengalami peristiwa, sebagaimana peristiwa yang digambarkan dalam sebuah alur. Dari pengertian tersebut.

Kepribadian tokoh sangat berpengaruh dalam perjalanan peristiwa dalam sebuah karya fiksi. Peristiwa dalam kehidupan sehari-hari selalu diemban oleh tokoh-tokoh tertentu, pelaku mengamban peristiwa dalam cerita fiksi sehingga peristiwa itu mampu menjalin suatu cerita melalui tokohtokohnya.

Tokoh dapat dibedakan menjadi beberapa jenis. Dikaji dari keterlibatannya dalam keseluruhan cerita, tokoh fiksi 
menurut Sayuti (2000: 74) dibedakan menjadi dua, yaitu tokoh sentral (utama) dan tokoh tambahan (bawahan peripheral). Tokoh utama atau tokoh sentral adalah tokoh yang mengambil bagian terbesar dalam peristiwa cerita, dengan kata lain tokoh utama merupakan tokoh yang paling banyak diceritakan. Volume kemunculan tokoh utama lebih banyak dibanding tokoh lain, sehingga tokoh utama biasanya, memegang peranan penting dalam setiap peristiwa yang diceritakan. Kemudian tokoh tambahan atau tokoh bawahan adalah tokoh yang dimunculkan sekali atau beberapa kali (peripheral character), tokoh-tokoh yang mendukung atau membantu tokoh sentral.

Meskipun kata tokoh dan penokohan sering digunakan orang untuk menyebut hal yang sama atau kurang lebih sama, sebenarnya keduanya tidaklah mengacu pada hal yang sama persis. Kata tokoh menyaran pada pengertian orang atau pelaku yang ditampilkan dalam sebuah karya fiksi. Adapun penokohan ialah pelukisan gambaran yang jelas tentang seseorang yang ditampilkan dalam sebuah cerita (Jones dalam risman, 2018).

Tokoh Utama merupakan orang-orang yang ditampilkan dalam sebuah cerita naratif atau drama pada pelaku utama, yang oleh pembaca ditampilkan memiliki kualitas moral dan kecenderungan tertentu seperti yang diekspresikan dalam ucapan dan apa yang dilakukan dalam perbuatan (Abrams melalui Nurgiyantoro, 2002: 85). Ia adalah pelaku yang mengembangkan peristiwa dalam cerita fiksi sehingga peristiwa itu mampu menjalin sebuah cerita (Aminuddin, 2010: 79). Dengan demikian, penokohan memiliki cakupan orang yang ditampilkan dalam sebuah cerita fiksi dan penggambarannya. Di samping kedua istilah di atas, sering pula digunakan kata watak dan perwatakan mengarah pada sifat dan sikap tokoh cerita. Watak lebih mengacu pada gambaran kualitas pribadi tokoh yang ditampilkan dalam sebuah cerita.

Pelaku pelukisan rupa, watak atau pribadi tokoh dalam sebuah karya fiksi disebut perwatakan atau penokohan. Sedangkan kepribadian, atau dalam bahasa Inggris characterization, berarti pemeranan, pelukisan watak. Minderop (2005: 2) berpendapat bahwa karakterisasi adalah metode melukiskan watak para tokoh yang terdapat dalam suatu karya fiksi. Dengan kata lain, penokohan, perwatakan ataupun karakterisasi menyaran pada hal yang sama, cara melukiskan watak tokoh.

Sumardjo (2004: 56) mengatakan dalam pelukisan kepribadian yang baik adalah menggambarkan watak dalam setiap ceritanya, sehingga pembaca melihat dengan jelas watak pelakunya melalui semua tingkah laku, semua yang diucapkannya, semua sikapnya dan semua yang dikatakan orang lain tentang tokoh ini dalam seluruh cerita. Kepribadian merupakan pola pelukisan image seseorang yang dapat dipandang dari segi fisik, psikis dan sosiologi. Segi fisik, pengarang melukiskan karakter pelaku misalnya, tampang, umur, raut muka, rambut, bibir, hidung, bentuk kepala, warna kulit dan lainlain. Segi psikis, pengarang melukiskan karakter pelaku melalui pelukisan gejalagejala pikiran, perasaan dan kemauannya.

Dengan jalan ini pembaca dapat mengetahui bagaimana watak pelaku. Segi sosiologis, pengarang melukiskan watak pelaku melalui lingkungan hidup kemasyarakatan. Dapat disimpulkan, seorang tokoh dalam karya sastra yang memiliki bersifat lifelike, di samping selalu merupakan hasil penjelmaan fisiknya, juga merupakan hasil penjelmaan pengaruhpengaruh lingkungannya. Oleh karena itu, dalam memahami tokoh, aspek-aspek yang 
melekat pada diri tokoh: seperti penamaan, peran, keadaan fisik, keadaan psikis, dan karakter perlu mendapat perhatian. Sebagaimana yang disinyalir (Wiyatmi, 2006: 45), aspek-aspek itu akan saling berhubungan dalam upaya membentuk dan membangun permasalahan dan konflik dalam sebuah lakon. Mengabaikan salah satu dari ketiga dimensi itu, tokoh akan menjadi timpang atau tidak berkepribadian.

Ada dua cara yang lazim dipergunakan untuk menampilkan tokoh di dalam cerita, yaitu dengan cara langsung dan tidak langsung. Ada pula yang membedakan cara-cara dalam menggambarkan tokoh tersebut, Sayuti (2000: 89) mengungkapkan, ada yang menjadikannya cara analitik dan dramatik, ada yang membedakannya menjadi metode langsung dan tak langsung, ada yang menbedakannya menjadi metode telling 'uraian' dan showing 'ragaan', dan ada pula yang membedakannya menjadi metode diskursif, dramatik, kontekstuat, dan campuran. Pembedaan yang berlainan itu sesungguhnya memiliki esesnsi yang kurang lebih sama.

\section{Psikologi Sastra}

Psikologi secara sempit dapat diartikan sebagai ilmu tentang jiwa. Sedangkan sastra adalah ilmu tentang karya seni dengan tulis-menulis. Maka jika diartikan secara keseluruhan, psikologi sastra merupakan ilmu yang mengkaji karya sastra dari sudut kejiwaannya. Menurut Wellek dan Austin (2009: 90), Istilah psikologi sastra mempunyai empat kemungkinan pengertian. Yang pertama adalah studi psikologi pengarang sebagai tipe atau sebagai pribadi. Yang kedua adalah studi proses kreatif. Yang ketiga studi tipe dan hukum-hukum psikologi yang diterapkan pada karya sastra. Dan yang keempat mempelajari dampak sastra pada pembaca (psikologi pembaca). Pendapat Wellek dan Austin tersebut memberikan pemahaman akan begitu luasnya cakupan ilmu psikologi sastra. Psikologi sastra tidak hanya berperan dalam satu unsur saja yang membangun sebuah karya sastra. Mereka juga menyebutkan, "Dalam sebuah karya sastra yang berhasil, psikologi sudah menyatu menjadi karya seni, oleh karena itu, tugas peneliti adalah menguraikannya kembali sehingga menjadi jelas dan nyata apa yang dilakukan oleh karya tersebut"

Menurut Ratna (dalam Iye 2018), "Psikologi Sastra adalah analisis teks dengan mempertimbangkan relevansi dan peranan studi psikologis". Artinya, psikologi turut berperan penting dalam penganalisisan sebuah karya sastra dengan bekerja dari sudut kejiwaan karya sastra tersebut baik dari unsur pengarang, tokoh, maupun pembacanya. Dengan dipusatkannya perhatian pada tokoh-tokoh, maka akan dapat dianalisis konflik batin yang terkandung dalam karya sastra. Secara umum dapat disimpulkan bahwa hubungan antara sastra dan psikologi sangat erat hingga melebur dan melahirkan ilmu baru yang disebut dengan "Psikologi Sastra". Artinya, dengan meneliti sebuah karya sastra melalui pendekatan Psikologi Sastra, secara tidak langsung kita telah membicarakan psikologi karena dunia sastra tidak dapat dipisahkan dengan nilai kejiwaan yang mungkin tersirat dalam karya sastra tersebut.

\section{Unsur Pembangun Novel}

Langkah awal dalam sebuah penelitian karya sastra adalah dengan menggunakan analisis struktural. (Abrams dalam Nurgiyantoro, 2002: 36) menjelaskan bahwa "struktur karya sastra dapat diartikan sebagai susunan, penegasan dan gambaran 
semua bahan dan bagian yang menjadi komponennya yang secara bersama membentuk kebulatan yang indah". Analisis struktural merupakan salah satu kajian kesusastraan yang menitikberatkan pada hubungan antarunsur pembangun karya sastra. Struktur yang membentuk karya sastra tersebut yaitu: penokohan, alur, pusat pengisahan, latar, tema, dan sebagainya. Struktur novel yang hadir di hadapan pembaca merupakan sebuah totalitas. Novel yang dibangun dari sejumlah unsur akan saling berhubungan secara saling menentukan sehingga menyebabkan novel tersebut menjadi sebuah karya yang bermakna hidup. Adapun struktur pembangun karya sastra yang dimaksud dan akan diteliti meliputi: unsur intrinsik dan unsur ekstrinsik.

\section{Unsur Instrinsik}

Unsur instrinsik merupakan unsurunsur yang membangun karya sastra itu sendiri. unsur-unsur inilah yang menyebabkan karya sastra hadir sebagai karya, unsur-unsur yang secara faktual akan dijumpai jika orang membaca karya sastra. Unsur instrinsik sebuah novel adalah unsur-unsur yang secara langsung turut serta membangun cerita.

Kepaduan antar unsur instrinsik inilah yang membuat sebuah novel berwujud. Hal-hal yang terkandung di dalam unsur inatrinsik sangat berkaitan erat dengan jiwa serta bathin para sastrawan. Hal ini merupakan kungkungan yang akhirnya akan mengalami peledakan spontan yang akan dituangkan dalam karya sastra itu. Halhal semacam itu mempengaruhi pengarang atau sastrawan dalam perwujudan imajinasinya.

Jika dilihat dari sudut kita pembaca, unsur-unsur cerita inilah yang akan kita jumpai jika kita membaca sebuah novel. Unsur yang dimaksud untuk menyebut sebagian saja, misalnya, peristiwa, cerita, plot, penokohan, tema, latar, sudut pandang penceritaan, bahasa atau gaya bahasa, dan lain-lain.

\section{Unsur Ekstrinsik}

Unsur ekstrinsik adalah unsur-unsur yang berada di luar karya sastra itu, tetapi secara tidak langsung mempengaruhi bangunan bangunan atau sistem organisme karya sastra. Atau secara lebih khusus ia dapat dikatakan sebagai unsurunsur yang mempengaruhi bangun cerita sebuah karya sastra, namun sendiri tidak ikut menjadi bagian didalamnnya. Walau demikian, unsur ekstrinsik cukup barpengaruh terhadap totalitas bangun cerita yang dihasilkan. Pemahaman unsur ekstrinsik suatu karya, bagaimanapun, akan membantu dalam hal pemahaman makna karya itu mengingat bahwa karya sastra tak muncul dari situasi kekosongan budaya.

Sebagaimana halnya unsur instrinsik, unsur ekstrinsik juga terdiri dari sejumlah unsur. Unsur-unsur yang dimaksud antara lain adalah keadaan subsektifitas individu yang memiliki sikap, keyakinan, pandangan hidup yang kesemuanya itu akan mempengaruhi karya yang ditulisnya. Unsur ekstrinsik berikutnya adalah psikologi pengarang, psikologi pembaca, maupun penerapan prinsip psikologi dalam karya. Keadaan dilingkungan pengarang seperti ekonomi, poitik, sosial juga akan berpengaruh terhadap karya sastra, dan hal itu merupakan unsur ekstrinsik pula.

Dari pengelompokkan unsur-unsur pembangun novel yang telah dijelaskan di atas maka penelaah terhadap majas atau gaya bahasa termasuk unsur pembangun novel yaitu pada unsur instrinsik. Sehingga 
unsur instrinsik yang secara langsung turut serta membangun cerita.

\section{Pendekatan Psikologi Sastra}

Pendekatan Psikologi Sastra diterapkan dalam setiap penelitian sastra yang mempergunakan pendekatan psikologis. Umumnya, dalam setiap pelaksanaan pendekatan psikologis terhadap penelitian sastra, yang diambil dari teori psikoanalisis ini hanyalah bagian-bagian yang berguna dan sesuai saja, terutama yang berkaitan dengan pembahasan sifat dan perwatakan manusia. Pembahasan sifat dan perwatakan manusia tersebut meliputi cakupan yang relatif luas karena manusia senantiasa menunjukkan keadaan jiwa yang berbeda-beda.

Pendekatan Psikologi Sastra juga menguraikan kelainan atau gangguan jiwa, "Namun dapat dipastikan bahwa Psikoanalisis bukanlah merupakan keseluruhan dari ilmu jiwa, tetapi merupakan suatu cabang dan mungkin malahan dasar dari keseluruhan ilmu jiwa" (Calvin, dalam risman 2018). Berdasarkan pernyataan tersebut secara umum dapat disimpulkan bahwa psikoanalisis merupakan tombak dasar penelitian kejiwaan dalam mencapai tahap penelitian yang lebih serius, khususnya karya sastra dalam hal ini. Psikoanalisis dalam karya sastra berguna untuk menganalisis tokohtokoh dalam drama atau novel secara psikologis. Tokoh-tokoh tersebut umumnya merupakan imajinasi atau khayalan pengarang yang berada dalam kondisi jiwa yang sehat maupun terganggu, lalu dituangkan menjadi sebuah karya yang indah. Keadaan jiwa yang sehat dan terganggu inilah yang menjadi cermin lahirnya karya dengan tokoh berjiwa sehat maupun terganggu.
Dalam buku-bukunya yang lebih mutakhir, Freud meninggalkan pembagian lapisan kesadaran di atas, dan menggantinya dengan konsep yang lebih teknis.

\section{METODE PENELITIAN \\ Pendekatan dan Jenis Penelitian}

Metode dalam penelitian ini adalah deskriptif kualitatif. Endaswara (2003: 45) menjelaskan bahwa penelitian kualitatif dilakukan dengan tidak mengutamakan angka-angka, tetapi mengutamakan kedalaman penghayatan terhadap interaksi antara konsep yang sedang dikaji secara impiris. Yang paling cocok untuk fenomena sastra adalah penelitian kualitatif. Ciri penting penelitian kualitatif dalam kajian sastra:

1. Penelitian merupakan instrumen kunci yang akan membaca secara cermat sebuah karya sasta,

2. Penelitian dilakukan secara deskriptif yaitu terurai dalam bentuk kata-kata atau gambar jika diperlukan, bukan bentuk angka-angka,

3. Lebih mengutamakan proses dibandingkan hasil, karena karya sastra merupakan fenomena yang banyak mengandung penafsiran,

4. Analisis secara induktif, dan

5. Makna merupakan andalan utama.

Adapun jenis penelitian dalam penelitian ini adalah kepustakaan. Peneliti akan mendeskripsikan secara jelas Analisis Kepribadian Tokoh Utama Ayah dalam Novel Ayah Menyayangi Tanpa Akhir karya Kirana Kejora dalam kajian psikologi sastra, yang di peroleh dalam kepustakaan yang tersedia.

\section{Sumber Data dan Jenis Data}

Data yang dimaksud dalam penelitian ini adalah kata, kalimat atau paragraf yang terdapat pada Kepribadian Tokoh Utama 
Ayah dalam Novel Ayah Menyayangi Tanpa Akhir karya Kirana Kejora dalam kajian psikologi sastra.

Sumber data dalam penelitian ini adalah sumber data tertulis yaitu teks Novel Ayah Menyayangi Tanpa Akhir karya Kirana Kejora, penerbit Zettu, Jakarta Timur (Cetakan Kedua, 2013), Tebal Buku: 372 Halaman.

\section{Teknik Pengumpulan Data}

Pengumpulan data merupakan bagian yang terpenting dalam sebuah penelitian, suatu keharusan bagi seorang peneliti. Untuk mendapatkan data yang diperlukan dalam penelitian ini, peneliti menggunakan beberapa teknik pengumpulan data yaitu sebagai berikut:

a. Teknik baca yaitu teknik yang digunakan peneliti dengan membaca novel yang dijadikan objek kajiannya dari awal sampai akhir.

b. Teknik catat yaitu teknik yang digunakan peneliti untuk mencatat datadata (informasi) Novel Ayah Menyayangi Tanpa Akhir karya Kirana Kejora yang ditemukan dalam bacaan sesuai dengan permasalahan yang dibutuhkan dalam penelitian, yaitu berupa kepribadian tokoh utama ayah.

\section{Teknik Analisis Data}

Setelah data terkumpul, langkah yang ditempuh selanjutnya adalah menganalisis data tersebut berdasarkan prinsip-prinsip analisis data kualitatif. Dalam menganalisis data dalam penelitian ini, Pendekatan yang digunakan adalah pendekatan psikologi sastra.

Penelitian psikologi sastra dapat dilakukan dengan dua cara, yaitu pertama, melalui pemahaman teori-teori psikologi kemudian dilakukan analisis terhadap suatu karya sastra yaitu Novel Ayah Menyayangi
Tanpa Akhir karya Kirana Kejor. Kedua, dengan terlebih dahulu menentukan sebuah karya sastra yaitu Novel Ayah Menyayangi Tanpa Akhir karya Kirana Kejora sebagai objek penelitian, kemudian ditentukan teoriteori psikologi yang dianggap relevan untuk melakukan analisis.

Penelitian sebuah karya sastra diperlukan pendekatan, dalam penulisan ini digunakan pendekatan psikologi sastra. Jika peneliti sastra ingin mengetahui sebuah makna dalam sebuah karya sastra maka peneliti harus menganalisis aspek yang membangun karya tersebut dan menghubungkan dengan aspek lain sehingga makna yang terkandung dalam sebuah karya sastra mampu dipahami dengan baik.

\section{PEMBAHASAN}

\section{Hasil Penelitian}

Salah satu pendekatan yang menajadi kajian dalam penelitian ini adalah pendekatan psikologi sastra. Psikologi sastra merupakan cabang penelitian sastra yang bersifat reflektif. Penelitian ini banyak diminati oleh peneliti yang ingin melihat sastra sebagai cermin kehidupan masyarakat. Novel Ayah Menyayangi Tanpa Akhir ini merupakan kajian psikologi Tokoh Utama Ayah yang terdapat nilai yang sangat urgen dalam kehidupan Masyarakat, adapun tokoh ayah yang dimaksud dalam neovel ini adalah Arjuna yang biasa dipanggil Juna, penulis memberikan gambaran umum novel yang tentang tinjauan psikologi.

\section{Aspek Id}

Psikologi aspek Id adalah satusatunya komponen kepribadian yang hadir sejak lahir. Aspek kepribadian sepenuhnya sadar dan termasuk dari perilaku naluriah dan primitif. Id adalah 
sumber segala energi psikis, sehingga komponen utama kepribadian. Id yang didorong oleh prinsip kesenangan, yang berusaha untuk kepuasan segera dari semua keinginan dan kebutuhan. Jika kebutuhan ini tidak puas, hasilnya adalah kecemasan atau ketegangan. Adapun aspek id psikologi tokoh utama dalam Novel Ayah Menyayangi Tanpa Akhir Karya Kirana Kejora terdapat 11 kutipan sebagai berikut:

\section{Data 1}

Juna begitu kaget, lalu tersenyum dan bergumam lirih, ini baru salah satu sensasi menjadi ayah dan ibu! Ia menghibur diri sendiri sambil mengusap air kencing Mada yang sukses membasahi seluruh wajahnya. (Hal: 17)

Kutipan di atas ditandai dengan kalimat Juna begitu kaget, lalu tersenyum dan bergumam lirih, ini baru salah satu sensasi menjadi ayah dan ibu. Kalimat ini merupakan aspek Id karena kata senyum merupakan hal yang menjadi pendorong oleh prinsip tokoh utama, yang mempunyai komponen kepribadian yang hadir sejak lahir.

\section{Data 2}

"Mada mau dibikin susu ayah... "Ayah masih sibuk. Ini pekerjaan masih banyak.”Juna gembira sekali melihat Mada sudah mau minum susu di gelas. "Di gelas? Hore! Anak ayah pintar. Suda gede, nggak ngedot lagi!" (Hal: 19)

Kutipan di atas ditandai dengan kalimat Juna gembira sekali melihat Mada sudah mau minum susu di gelas. Kalimat ini merupakan aspek Id karena kata gembira sekali merupakan hal yang menjadi pendorong oleh prinsip tokoh utama, yang mempunyai komponen kepribadian yang hadir sejak lahir.

\section{Data 3}

"Anak Ayah sudah besar. Tampan!” "yah! Ayah malu! Jangan begitu!" "Dimanapun seorang ayah akan berkata begitu ke anak lelakinya!"(Hal:41)

Kutipan di atas ditandai dengan kalimat Anak Ayah sudah besar. Tampan!” “yah! Ayah malu! Jangan begitu. Kalimat ini merupakan aspek Id karena kata tampan merupakan hal yang menjadi pendorong oleh prinsip tokoh utama, yang mempunyai komponen kepribadian yang hadir sejak lahir. Juna menepuk dahinya, ia lupa jadwa karnaval Mada yang sudah pernah disampaikan Mbok Jum beberapa hari sebelumnya. (Hal: 44)

\section{Aspek Ego}

Psikologi sastra pada aspek ego adalah komponen kepribadian yang bertanggung jawab untuk menangani dengan realitas. Ego berkembang dari id dan memastikan bahwa dorongan dari id dapat dinyatakan dalam cara yang dapat diterima di dunia nyata. Fungsi ego baik di pikiran sadar, prasadar, dan tidak sadar. Adapun aspek id psikologi tokoh utama dalam Novel Ayah Menyayangi Tanpa Akhir Karya Kirana Kejora terdapat 15 kutipan sebagai berikut:

\section{Data 1}

Juna memanggil Mbok Jum, namun segera Mada membalikan badan, menutup bibir ayahnya, mentapnya lekat, memohon. (Hal: 19)

Kutipan di atas ditandai dengan kalimat Juna memanggil Mbok Jum, namun segera Mada membalikan badan, menutup bibir ayahnya, mentapnya lekat, memohon. Kalimat tersebut merupakan tokoh utama ayah psikologi dari aspek ego yaitu kepribadian yang bertanggung jawab untuk menangani dengan realitas, karena ia ingin mendapat sesuatu.

\section{Data 2}

"Mada mau dibikin susu ayah... "Ayah masih sibuk. Ini pekerjaan masih banyak."Juna gembira sekali melihat Mada 
sudah mau minum susu di gelas. "Di gelas? Hore! Anak ayah pintar. Suda gede, nggak ngedot lagi!" (Hal: 19)

Kutipan di atas ditandai dengan kalimat Ayah masih sibuk. Ini pekerjaan masih banyak. Kalimat tersebut merupakan tokoh utama ayah psikologi dari aspek ego karena Ayahnya lebih mengutamakan pekerjaannya daripada membuatkan susu untuk anaknya, aspek ego dari kepribadian yaitu lebih mementingkan diri sendiri.

\section{Data 3}

Lalu mesin mobil Juna terasa berat, seperti ikut terbebani sekian ton beban luka hatinya. Yang terus deras semakin membuat hatinya pandangan berkabut. (Hal: 22)

Kutipan di atas ditandai dengan kalimat Yang terus deras semakin membuat hatinya pandangan berkabut. Kalimat tersebut merupakan tokoh utama ayah psikologi dari aspek ego yaitu kepribadian yang bertanggung jawab untuk menangani dengan realitas, karena ia ingin mendapat sesuatu.

\section{Aspek Super Ego}

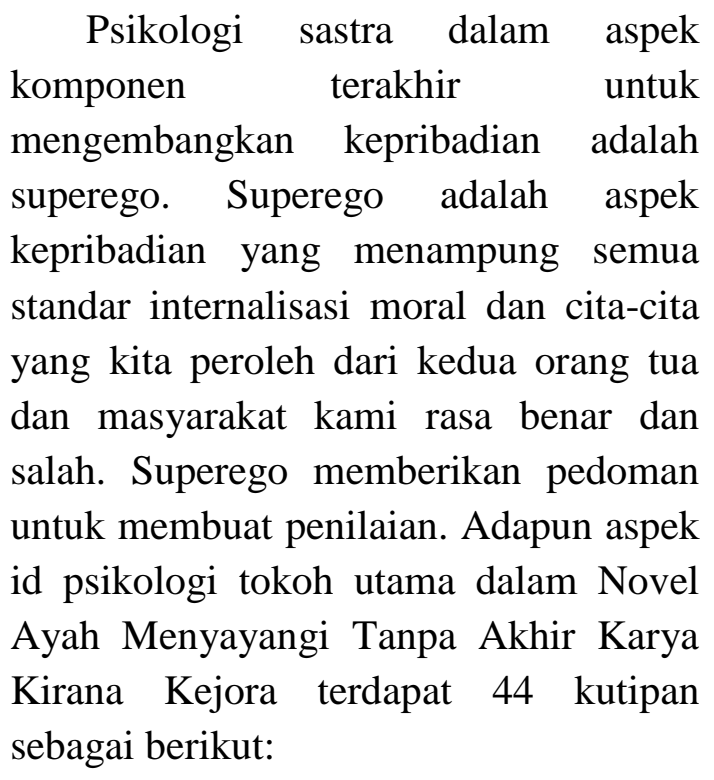

\section{Data 1}

Malam penuh kebodohan. Juna baru sadar persediaan obat-obatan dirumah sudah menipis, dan penurun panas untuk Mada pun habis. Dungunya si ayah yang apoteker ini! Rutuknya dalam hati. (Hal: 18)

Kutipan di atas ditandai dengan kalimat Juna baru sadar persediaan obat-obatan dirumah sudah menipis, dan penurun panas untuk Mada pun habis. Kalimat tersebut merupakan aspek Superego yang merupakan kepribadian yang menampung semua standar internalisasi moral dan citacita yang kita peroleh dari kedua orang tua dan masyarakat kami rasa benar dan salah.

\section{Data 2}

Tengah malam Juna baru terbangun dan segera merebahkan Mada di tempat tidur. Menunjukan suhu tubuh Mada kembali normal. (Hal: 18)

Kutipan di atas ditandai dengan kalimat Tengah malam Juna baru terbangun dan segera merebahkan Mada di tempat tidur. Kalimat tersebut merupakan aspek Superego yang merupakan kepribadian yang menampung semua standar internalisasi moral dan cita-cita yang kita peroleh dari kedua orang tua dan masyarakat kami rasa benar dan salah.

\section{Data 3}

Juna merasa takjub, pertama kali memperhatikan Madan minum susu dari gelasnya, membuat hatinya berbunga. (Hal: 20)

Kutipan di atas ditandai dengan kalimat Juna merasa takjub, pertama kali memperhatikan Madan minum susu dari gelasnya, membuat hatinya berbunga. Kalimat tersebut merupakan aspek Superego yang merupakan kepribadian yang menampung semua standar internalisasi moral dan cita-cita yang kita peroleh dari kedua orang tua dan masyarakat kami rasa benar dan salah.

\section{Data 4}


"Mada mau diantar Ibu..." Juna shock dengan jawaban Mada yang tak pernah ia sangka. (Hal: 24)

Kutipan di atas ditandai dengan kalimat Juna shock dengan jawaban Mada yang tak pernah ia sangka. Kalimat tersebut merupakan aspek Superego yang merupakan kepribadian yang menampung semua standar internalisasi moral dan citacita yang kita peroleh dari kedua orang tua dan masyarakat kami rasa benar dan salah.

\section{PENUTUP}

\section{Simpulan dan Saran}

Berbagai temuan yang penulis dapat ditemukan dalam kajian psikologi sastra pada novel Ayah Menyayangi Tanpa Akhir karya Kirana Kejora yaitu: Psikologi sastra dalam Aspek id, Aspek ego dan Aspek superego.

Kajian psikologi sastra aspek Id adalah satu-satunya komponen kepribadian yang hadir sejak lahir. Aspek kepribadian sepenuhnya sadar dan termasuk dari perilaku naluriah dan primitif. Id adalah sumber segala energi psikis, sehingga komponen utama kepribadian. Id yang didorong oleh prinsip kesenangan, yang berusaha untuk kepuasan segera dari semua keinginan dan kebutuhan. Jika kebutuhan ini tidak puas, hasilnya adalah kecemasan atau ketegangan. Adapun aspek id psikologi tokoh utama dalam Novel Ayah Menyayangi Tanpa Akhir Karya Kirana Kejora terdapat 11 kutipan.

Kajian psikologi sastra pada aspek ego adalah komponen kepribadian yang bertanggung jawab untuk menangani dengan realitas. Fungsi ego baik di pikiran sadar, prasadar, dan tidak sadar. Adapun aspek id psikologi tokoh utama dalam Novel Ayah Menyayangi Tanpa Akhir Karya Kirana Kejora terdapat 15 kutipan.
Kajian psikologi sastra dalam aspek komponen terakhir untuk mengembangkan kepribadian adalah superego. Superego adalah aspek kepribadian yang menampung semua standar internalisasi moral dan citacita yang kita peroleh dari kedua orang tua dan masyarakat kami rasa benar dan salah. Superego memberikan pedoman untuk membuat penilaian. Adapun aspek id psikologi tokoh utama dalam Novel Ayah Menyayangi Tanpa Akhir Karya Kirana Kejora terdapat 44 kutipan.

\section{DATAR PUSTAKA}

Aminuddin. 2010. Pengantar Apresiasi Karya Sastra. Bandung: Sinar Baru Algensindo.

Junaedie, H. Moha. 2005. Dasar-Dasar Kajian Sastra dan Penerapannya. Ujung Pandang: CV. Putra Maspul Offset.

Nurgiyantoro, Burhan. 2002. Teori Pengkajian Fiksi. Yogyakarta: Gajahmada University Press.

Minderop, Suarjin. 2005. Dasar-dasar Kajian Sastra dan Penerapannya. Yogyakarta: Kanisius.

Iye, R. (2018). Tuturan emosi mahasiswa kota baubau dalam ranah demonstrasi [emotional speech of the students in baubau city in the demonstration]. TOTOBUANG, 6 (1), 125, 138.

Iye, R., \& Susiati, S. (2018). NILAI EDUKATIF DALAM NOVEL SEBAIT CINTA DI BAWAH LANGIT KAIRO KARYA MAHMUD JAUHARI ALI (Educative Values in Sebait Cinta di Bawah Langit Kairo by Mahmud Jauhari Ali). Sirok Bastra, 6 (2), 185191.

Iye, R. J1 Prof Dr HAR Basalamah No, and Namlea-Kab Buru.". TUTURAN DALAM PROSESI LAMARAN PERNIKAHAN DI TOMIA 
KABUPATEN WAKATOBI."

Kontemporer. Bandung: PT Remaja.

Iye, R., \& Susiati, S. (2018). NILAI

EDUKATIF DALAM NOVEL

SEBAIT CINTA DI BAWAH

LANGIT KAIRO KARYA

MAHMUD JAUHARI ALI

(Educative Values in Sebait Cinta di

Bawah Langit Kairo by Mahmud

Jauhari Ali). Sirok Bastra, 6 (2), 185-

191.

Sayuti, Suminto A. 2000. Berkenalan dengan prosa fiksi. Yogyakarta: Gama Media.

Sudjiman, Panuti. 2004. Kajian Teologi Sastra. Jakarta: Divva Pres.

Suharso, 2002. Analisis Sastra Tingkat Mahasiswa. Jakarta: Departemen Pendidikan dan Kebudayaan.

Sumardjo, Djakob. 2004. Kajian Sosiologi Teori dan Praktek. Yogyakarta: Aura Pustaka.

Wellek, Rene dan Austin Warren. 2009. Teori Kesusasteraan. Diterjemahkan dalam Bahasa Indonesia oleh Melani Budianta. Jakarta: Gramedia Pustaka Utama.

Wiyatmi. 2006. Psikologi Sastra. Yogyakarta: Kanwa Publiser. 